Journals.ASM.org

\title{
Biographical Feature
}

\section{Raymond C. Bartlett, M.D.}

Andrew B. Onderdonk, Editor, Journal of Clinical Microbiology

Brigham and Women's Hospital, Harvard Medical School, Boston, Massachusetts, USA

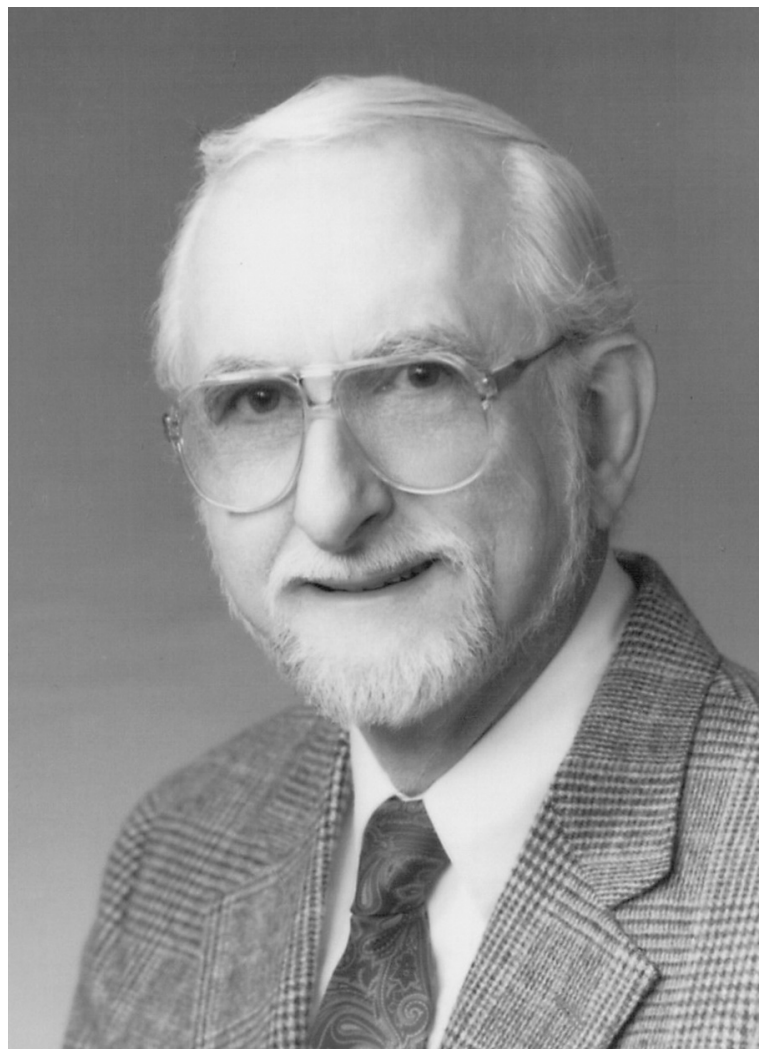

s I began reviewing biographical information about Dr. Raymond C. Bartlett in preparation for writing this brief biographical feature, it suddenly occurred to me that this was a rare opportunity to think about the trajectory of my own career path and the influence that some of the visionary clinical microbiologists such as Dr. Raymond Bartlett had on the way clinical microbiology laboratories operate today. I first met Dr. Bartlett during a workshop put on by my infectious diseases group, which had newly arrived in Boston, dealing with the isolation and identification of clinically significant obligate anaerobes. I knew from colleagues that Dr. Bartlett was considered a controversial figure in the clinical microbiology field, but it was not until much later that I came to understand Dr. Bartlett's vision for the modern clinical microbiology laboratory and the controversy that came with his singular pursuit of this vision. As it turns out, Dr. Bartlett was probably 20 years ahead of his time in his thinking about quality assurance, quality improvement, appropriate specimens for microbiologic analysis, infection control, and effective cost manage- ment in the clinical microbiology laboratory. Virtually all of his concepts have been adopted in some form within today's clinical microbiology laboratory as standard operating procedures.

Raymond Clark Bartlett was born on 12 September 1930 in Brooklyn, NY, to Kathryn (Clark) and Hall Bartlett. He was named after his grandfather, Dr. Raymond Clark, a prominent local physician. Raymond spent most of his childhood years in the New York City/Long Island area, where his father taught history. He obtained his early education at local schools and spent his

Accepted manuscript posted online 11 February 2015

Citation Onderdonk AB. 2015. Raymond C. Bartlett, M.D. J Clin Microbiol 53:1464-1466. doi:10.1128/JCM.00167-15.

Editor: B. A. Forbes

Copyright @ 2015, American Society for Microbiology. All Rights Reserved. doi:10.1128/JCM.00167-15 
summers at a family compound on a lake, often working with his grandfather to maintain and improve the facilities. According to Raymond's memoir, "Dr. Clark professed a work ethic that all but precluded having tradesmen help him. He deplored short-cuts. Young Raymond heard over and over that there is something wrong with a man who always wants to do things the easy way." This was perhaps prophetic of Dr. Bartlett's later career path.

Raymond attended Columbia College at Columbia University and graduated with a B.A. degree in 1952, with the intention of pursuing a degree in medicine. He was accepted to the College of Physicians and Surgeons at Columbia University, where he graduated in 1956. During his third year of medical school, he met his future wife, Esther Rosengren, a nursing student. They were married a year later in Saint Paul's Chapel at Columbia University, shortly before he began his internship year.

Medical school was followed by an internship and residency training in pathology at Hartford Hospital, beginning in the summer of 1956. Following a hectic year as an intern, Raymond began a more measured residency program in pathology, where he had time to learn more about underlying disease processes through autopsy evaluations, microscopic review of tissue specimens, and reading and evaluating relevant literature. However, by the end of the first year of his residency training, Raymond had shifted his interests from the purely pathological aspects of disease to include the growth and administration of the pathology laboratory enterprise. According to his memoir, "all of the growth in the Pathology laboratory was taking place in the clinical pathology divisions." Clinical pathology laboratories were generating great amounts of revenue from insurance companies that paid for patient testing. However, Dr. Bartlett felt that the costs of testing would at some point result in a decline in the revenues received, which would necessitate changes in how clinical laboratories operated. During his final 2 years of resident training, he spent a great deal of time reviewing data on laboratory testing and procedures, including working with the administrative and financial staff of the hospital on many occasions to better understand costs associated with testing. On 1 July 1961, Raymond began his tenure as a faculty member of the pathology department at Hartford Hospital. Initially, he spent most of his time devoted to the autopsy and surgical pathology services. Since many faculty members in anatomic pathology also had some responsibility for a clinical pathology area, Raymond gravitated toward the microbiology laboratory, where the chief technologist was nearing retirement age, providing an opportunity for Raymond to step into the administrative leadership of the laboratory. In order to prepare himself to administer a clinical microbiology laboratory, Raymond read the available textbooks on clinical microbiology and attended as many seminars and workshops on the topic as he could. It was as part of this effort that Raymond met Drs. Harding and Sommers, two pathologists that had specialized in clinical microbiology and were also prominent members of the American Society for Clinical Pathology (ASCP). Dr. Harding, the chair of the council on microbiology for the ASCP at the time, was impressed with the enthusiasm that Raymond demonstrated and invited him to help with hands-on workshops and seminars on clinical microbiology for pathologists despite his lack of formal training in clinical microbiology. Raymond was an extremely well organized and effective teacher (having attended seminars given by Dr. Bartlett, I can attest to this fact), and by 1967, he had been asked to chair the council on microbiology for the ASCP. As noted by Raymond, "The student had become the teacher."

Raymond started attending the meetings held by the American Society for Microbiology (ASM), where he noted that most of the clinical microbiologists directing laboratories held Ph.D. degrees in microbiology but that pathologists did not have sufficient specialized training and expertise to effectively manage a clinical microbiology laboratory. Raymond also noted that many clinical microbiology laboratories at the time were run by poorly trained technologists using methods and techniques that were of dubious value for patient care. In late 1961, Raymond became the director of the Division of Microbiology at Hartford Hospital and began implementing his program for laboratory management.

One of the first areas that Raymond focused on after assuming the directorship of the clinical microbiology laboratory was quality control, a subject that he had been introduced to during his rotations in clinical chemistry and hematology, where quantitative information could be subjected to quality control practices. According to Raymond's memoir, the genesis of quality control activities in clinical pathology was a result of proficiency testing put into place by various governmental agencies for chemistry and hematology laboratories once it was learned that some laboratories, perhaps overwhelmed with samples, were simply pouring samples down the drain and reporting a normal result, based on the knowledge that most samples tested yielded a normal result. However there were no recommendations up to that point in time for clinical microbiology laboratories to assess the quality of the work performed. Raymond systematically began putting controls in place for the microbiology laboratory, starting with test organisms for specialized media used to isolate pathogens such as Bordetella pertussis. Most laboratories still made their own agar plates and broth media at the time, often without any assessment of whether the final product would grow the organism(s) for which it was intended. He also "introduced many other controls in his laboratory to assure that chemical tests performed for identification purposes on bacteria growing in culture were accurate." One of his most cost-effective methods for evaluating whether a specimen was appropriate for culture was to use the Gram stain to look for both specific organism morphology and the neutrophils normally associated with inflammatory exudates. By rejecting specimens lacking neutrophils or containing large numbers of squamous epithelial cells, Raymond felt that he would be providing better, less-misleading information for clinicians. He was among the very first clinical microbiologists to recognize that humans have a normal microflora and that just because bacteria are isolated from a specimen does not mean that they are necessarily causing an infectious process, particularly if multiple organisms with different phenotypes are found within a specimen from a site where bacteria are normally present. Raymond was anxious to share his experiences with others and began presenting his program on quality control in the microbiology laboratory at various meetings, including the 1967 ASM meeting held in New York City.

In recognition of the inconsistent information that flowed from clinical laboratories in support of patient care activities, Congress passed the first Clinical Laboratory Improvement Act (CLIA) in 1967. Recommendations and administration of the program were to be performed by the Center for Disease Control (CDC). In an effort to develop guidelines consistent with the intent of the CLIA, Dr. Pentti Kokko, the director of the CDC, invited Raymond to talk with his staff regarding his program for 
quality control in the microbiology laboratory. Raymond's recommendations were incorporated almost without exception into the guidelines and became a part of the federal regulations for clinical laboratories.

Adoption of the new CLIA regulations was not always received with open arms within the clinical microbiology community, and when Raymond published his book Clinical Microbiology: Quality Cost and Clinical Relevance in 1974 (1), pointing out the deficiencies of long-standing practices of clinical microbiologists in the collection, processing, reporting, and interpretation of results, it created a firestorm of controversy that came to a head at the 1974 ASM meeting held in Chicago, IL. Raymond participated in a panel discussion, where he shared his views on quality control in the clinical microbiology laboratory. This event was described by one of Raymond's former students, James McLaughlin, as follows: "Dr. Bartlett didn't even have the support of the other members of the panel. Dr. Bartlett's thinking was so far in front of the traditional microbiologists that he suffered the fate of the prophets. ..." At this meeting, Dr. Al Balows, Dr. Henry Isenberg, and Dr. Alex Sonnenwirth, three of the most prominent clinical microbiologists at the time, all took exception to what had been presented. This did not deter Raymond at all, and he continued to promote better quality control and operational practices within the microbiology laboratory, moving on from simple quality control issues to quality improvement efforts, infection control programs, and a relentless pursuit of the right balance for cost-effective application of these procedures within an ever-changing health care dynamic.

In 1965, he was appointed to the infection control committee for Hartford Hospital, and he quickly took over as the chairman for this committee in 1966. In 1969, he was appointed as the assistant director for the Department of Pathology. With these appointments in place, Dr. Bartlett was able to continue to implement changes throughout the hospital to better apply information gained from the clinical microbiology laboratory to patient care activities.

Raymond's efforts included a 2 -year postdoctoral training program that began in the mid-1960s and provided training in clinical microbiology. Ironically, this training program was certified by the ASM Board of Medical Microbiology at the same time as some prominent clinical microbiologists were condemning his philosophy. Dr. Bartlett was also appointed to the examination committee for the American Board of Pathology, bridging the chasm between clinical microbiology and pathology.

Dr. Bartlett was among the first to implement computer-generated reports for antibiotic susceptibility data, including the somewhat controversial practice of making an antibiotic treatment recommendation as part of the report. His concepts for quality management were very similar to those used in a variety of industrial settings and included the concepts of continuous quality improvement, management by objectives and communications between staff, and management on an ongoing basis. By the early 1980s, many clinical laboratories were embracing the concepts and practices put forward by Dr. Bartlett over a decade earlier. It was also becoming increasingly evident that the financing of the health care industry was undergoing major changes that were forcing hospitals and laboratories to find ways to cut costs while continuing to provide the best possible patient care.

In recognition of his many contributions to clinical pathology and clinical microbiology specifically, he was awarded the distinguished service award from the ASCP in 1978 and was, somewhat ironically, awarded the Alex Sonnenwirth award in 1990 by the ASM for his contributions to clinical microbiology. In 1994, following his retirement, Dr. Bartlett was awarded the Becton Dickinson Award by the ASM. One of his former students wrote in a letter of support, "Over 2 decades ago, Dr. Bartlett predicted the coming cost constraints on diagnostic laboratories and began to develop streamlined, yet clinically relevant approaches to microbiology testing. Dr. Bartlett is a man of integrity, who has contributed greatly to the field of microbiology and richly deserves this award."

As I reflect on the day-to-day operations in my own clinical microbiology laboratory, I realize that many of the practices that we have put in place are a direct result of the pioneering work of Dr. Raymond Bartlett. We are fortunate that Dr. Bartlett had the vision and tenacity to follow through on his ideas for how modern clinical microbiology laboratories should provide relevant patient information in an environment of cost containment.

\section{ACKNOWLEDGMENT}

I thank Dr. Ann Robinson for providing most of the source material used for this biographical sketch.

\section{REFERENCES}

1. Bartlett RC. 1974. Medical microbiology: quality cost and clinical relevance. John Wiley and Sons, New York, NY.

\section{SELECTED BIBLIOGRAPHY}

Bartlett RC, Mielert C, Irving W. 1968. Quality control in microbiology. American Society of Clinical Pathologists, Chicago, IL.

Bartlett RC, Mazens MF. 1971. Effect of plate size on zone diameter in the disc antimicrobial susceptibility test. Appl Microbiol 22:372-376.

Bartlett RC. 1974. A plea for clinical relevance in medical microbiology. Am J Clin Pathol 61:867-872.

Bartlett RC. 1974. Medical microbiology: quality cost and clinical relevance. John Wiley and Sons, New York, NY.

Bartlett RC. 1974. Infection Surveillance and Control, p 841-851. In Lennette EJ, Spaulding EH, Truant JP (ed), Manual of clinical microbiology, 2nd ed. ASM Press, Washington, DC.

Bartlett RC. 1979. The health care value of laboratory tests. Conn Med 43: 354-363.

Bartlett RC, Rutz C. 1980. Processing control and cost in bacteriology. Am J Clin Pathol 74:287-296.

Bartlett RC. 1982. Medical microbiology: how far to go, how fast to go, $p$ 12-44. In Lorian V (ed), Significance of medical microbiology in the care of patients, 2nd ed. Williams and Wilkins, Baltimore, MD.

Bartlett RC. 1982. Making optimum use of the microbiology laboratory. I. Use of the laboratory. JAMA 247:857-859.

Bartlett RC, Treiber N. 1984.Clinical significance of mixed urine cultures. Am J Clin Pathol 82:319-322.

Bartlett RC. 1985. Effect of DRG's on utilization of the microbiology laboratory. Infect Control 6:323-324.

Bartlett RC. 1987. Quality assurance of commercially prepared microbiologic culture media. Clin Microbiol Newsl 9:29-30.

Bartlett RC. 1990. Trends in quality management. Arch Pathol Lab Med 114:1126-1130. 